Mathematical Problem-Solving. Journal for the Education of Gifted Young Scientists, 7(4), 1019-1036. DOI: http://dx.doi.org/10.17478/jegys.606031

7. Cegarra, J., Papa, A., Garcia-Perez, A., Fiano, F. An open-minded strategy towards eco-innovation: A key to sustainable growth in a global enterprise / J. Cegarra at all// Technological Forecasting and Social Change. - 2019. - 148. - 119727. 10.1016/j.techfore.2019.119727.

8. Haimovitz, K. and Dweck, C.S. The Origins of Children's Growth and Fixed Mindsets / K. Haimovitz and C.S. Dweck// New Research and a New Proposal. Child Dev. - 2017. - 88. - P. 1849-1859. doi:10.1111/cdev.12955

9. Hare, W. Objections to open-mindedness in teaching. In OpenMindedness and Education. - McGill-Queen's University Press, 1979. from http://www.jstor.org/stable/j.ctt7zx21.10

10. Klimanska, M., \& Haletska, I. (2019). Ukrainain adaptation of the short five factor personality questionnaire tipi (tipi-ukr). Psychological journal, 5(9), 57-76. https://doi.org/10.31108/1.2019.5.9.4

11. Lord, M. (2015). Group learning capacity: The roles of openmindedness and shared vision. Frontiers in psychology. 6. 150. 10.3389/fpsyg.2015.00150.

12. Mitchell, R and Nicholas, S (2006) Knowledge Creation in Groups: The Value of Cognitive Diversity, Transactive Memory, and Openmindedness Norms. The Electronic Journal of Knowledge Management, Volume 4 Issue 1
13. Ole Boe et al (2015) Selecting the most relevant character strengths for Norwegian Army officers: An educational too Procedia - Social and Behavioral Sciences, 197

14. Opykhailo O. B. (2014) Self-reported character strengths pertinent to gelotophobes, gelotophiles and katagelasticists. Вісник Дніпропетровського університету. Серія "Педагогіка і психологія ", 20.

15. Peterson, C., \& Seligman, M. E. P. (2004). Character strengths and virtues: A handbook and classification. Washington, DC: American Psychological Association.

16. Robertson, L. H., Robertson, T. J., Robertson, D. T. The opened mind: An application of the historical concept of openness to education. In D. Conrad \& P. Prinsloo (Eds.), Open(ing) education: Theory and practice. Leiden, Netherlands: 2020. - https://doi.org/10.1163/9789004422988_003

17. Sawatzky, D \& Zingle, H. (1969). Accurate Interpersonal Perception and Open-mindedness. Perceptual and motor skills. 29. 395-400. 10.2466/pms.1969.29.2.395.

18. Shearman, Sachiyo \& Levine, Timothy (2006). Dogmatism Updated: A Scale Revision and Validation. Communication Quarterly. 54. 275-291. 10.1080/01463370600877950.

19. Tjosvold, Dean; Poon, Margaret (1998). Dealing with scarce resources: openminded interaction for resolving budget conflicts. Group \& Organization Management. 23 (3)

Надійшла до редколегії 17.06.20

Рекомендована до друку 15.10.20

Svitlana Chunikhina, PhD (Psychology), Senior Researcher

Institute for Social and Political Psychology, NAES of Ukraine, Kyiv, Ukraine

\title{
PUBLIC ATTITUDES TOWARD EDUCATIONAL REFORMS: A STUDY OF THE PROBLEM OF OPEN-MINDEDNESS
}

The article reviews the problem of contradictory public attitude to educational reforms in connection with the phenomenon of openmindedness. Based on the review of case studies, two major areas of conceptualization of openness of judgments have been identified. The first direction studies the openness of judgments in the context of interpersonal interaction, as a lack of prejudice against members of groups that are interpreted as "others", willingness to tolerate "otherness" and productively interact with other people in conflict of opinions and positions. In the second direction, openness of judgment is seen primarily as a cognitive attitude to the perception of new ideas, tolerance of diversity of opinion and willingness to think outside the box ("out of box"). A sample of 230 respondents allowed to examine the relationship between cognitive (dogmatism) and personal (openness to new experiences) aspects of openness of judgment with a subjective attitude to educational reforms. Dogmatism is related to the tough judgments about educational reforms. More dogmatic respondents tend to have negative evaluations of reforms, less dogmatic ones are more likely to have no established evaluative judgments. Openness to new experiences determines the modality of assessments of educational reforms: more "open" respondents tend to be more positive about the changes that occur as a result of reforms than less "open" ones, which are characterized by a certain pessimism. It has been found that dogmatism and openness to new experiences manifest themselves in different ways in relation to educational reforms among professionals engaged in the field of education and non-professionally related to the education of respondents.

Keywords: openness of judgments, dogmatism, openness to new experiences, public attitude, educational reform

Bulletin of Taras Shevchenko National University of Kyiv. Series "Psychology". № 1(11), pp. 70-77 (2020)

УДК 159.923

DOI: https://doi.org/10.17721/BSP.2020.1(11).13
ISSN 1728-3817

(C) Taras Shevchenko National University of Kyiv,

Publishing and Polygraphic Center "Kyiv University", 2020

Ілля Ягіяєв, канд. психол. наук, асист. Аліна Новосельська, студ. Влада Келлер, студ. Марта Савич, студ.

Київского національного університету імені Тараса Шевченка, Київ, Україна

\section{ВИКОРИСТАННЯ СОЦІАЛЬНИХ МЕРЕЖ ТА СУБ'ЄКТИВНЕ БЛАГОПОЛУЧЧЯ В УМОВАХ ПАНДЕМІї COVID-19}

Актуальність теми пов'язана з психологічними наслідками пандемії COVID-19. Метою було дослідження суб'єктивного благополуччя на початку пандемії і запровадження карантинних заходів, та їхнього з6'язку з активністю у соціальних мережах. Використовувалися шкала позитивного та негативного афректу (Watson, Clark \& Tellegen, 1988), шкала задоволеності життям (SWLS) (Diener, Emmnos, Larsen, \& Griffin, 1985), шкала загальної самоефективності (Schwarzer \& Jerusalem, 1995), авторська анкета сприймання пандемії та уявлень про неї. Було визначено, що з суб'єктивним благополуччям під час пандемії пов'язані використання соціальних мереж, задоволеність життям, оцінка загрози для здоров'я та економічних наслідків, способи проведення вільного часу та рівень загальної самоефективності. Було здійснено якісний аналіз та визначено, що станом на початок епідемії в Україні у досліджуваних превалюють негативні прогнози наслідків епідемії та карантину. У лонгітюдній частині дослідження протягом місяця було виявлено зменшення рівня тривоги стосовно здоров'я, респонденти оцінювали загрозу своєму здоров'ю та економічні наслідки як менш серйозні, ніж на початку. Таким чином, загалом негативний афект у короткотривалій перспективі зменшився, особливо зменшились рівні страху та тривоги, проте рівень позитивного афекту не змінився.

Ключові слова: психологічне благополуччя, суб'єктивне благополуччя, пандемія, задоволеність життям, соціальні мережі, теорії змови, COVID-19.

Вступ. Пандемія COVID-19 стала серйозним випробуванням для людства у наші й так непевні та кризові для країни та світу загалом часи. Через пандемію COVID-19 у багатьох країнах світу було впроваджено карантин, що часто є неприємним досвідом для людей. Розлука з близькими, як і потреба постійно перебувати поряд із ними, втрата можливості вільного пересування, загальна непевність та нудьга можуть з часом спри- 
чиняти вельми негативні наслідки. Повідомлялося про самогубства, спалахи гніву та судові позови після введення карантину під час попередніх спалахів інфекційних захворювань (Schultz et al., 2008).

Іншим чинником, пов'язаним зі сприйманням пандемії, є використання соціальних мереж. Емпірично доведено існування зв'язку між використанням соціальних мережам та психологічним благополуччям (SampasaKanyinga Hugues et al., 2015, Utz \& Breuer, 2017). В умовах соціальної, економічної та епідеміологічної кризи соціальні мережі можуть швидко поширювати як надійну та перевірену інформацію, так і дезінфрормацію (Taylor, 2019; Tang, Bie, Park, \& Zhi, 2018). Вони можуть підживити або вгамувати страхи, а можуть навіть у непрямий спосіб впливати на поширення хвороби, скеровуючи поведінку людей.

Метою роботи є виявлення та аналіз зв'язку використання соціальних мереж та суб'єктивного благополуччя під час пандемії COVID-19 та карантинних заходів.

Відповідно до поставлених завдань у роботі застосовувалися такі методики: шкала позитивного та негативного афекту (PANAS) в авторському перекладі, шкала задоволеності життям (Е. Дінер), шкала загальної самоефективності (Р. Шварцер, М. Джерусалем) в авторському перекладі, власна розроблена анкета, яка стосується пандемії та уявлень про неї, у тому числі у контексті теорій змови.

Із статистичних методів обробки даних застосовувалися первинні описові статистики; t-критерій Стьюдента для незв'язаних вибірок з корекцією Уелча; величина ефекту для порівняння середніх за t-критерієм (d Коена); кореляційний аналіз (коєфіцієнти Пірсона та Спірмена залежно від ступеня нормальності розподілу, який визначався за асиметрією та ексцесом, а також візуальною оцінкою розподілу змінної); аналіз узгодженості питань шкал опитувальників ( $\alpha$ Кронбаха і $А 6$ Гутмана).

Основна частина. Огляд літератури. Аналізуючи дослідження на тематику психологічного благополуччя, було виявлено два вектори трактування та виміру благополуччя - у гедоністичній та евдемонічній перспективі (A. Delle Fave, F. Massimini, M. Bassi). Гедонізм визначає благополуччя як наявність позитивного афекту та відсутність негативного. Евдемонія у свою чергу не зводить благополуччя до максимізації позитивного досвіду та мінімізації негативного, а також враховує осмисленість та аутентичність життя, особистісне зростання та здійснення людського потенціалу.

У сучасній психології гедоністичну позицію пов'язують з концепцією суб'єктивного благополуччя (Е. Дінер, Р. Еммонс, Дж. Вотсон). Евдемонічні підходи яскраво представляє теорія психологічного благополуччя К. Ріффр, Е. Десі та Р. Райана, М. Чіксентміхаї тощо.

Пандемія - це масштабна епідемія, яка охопила мільйони людей у різних країнах, поширюючись по всьому світу. Пандемії пов'язані з низкою психосоціальних стресорів, включаючи загрозу своєму здоров'ю та здоров'ю близьких.

Соціальна дистанція та карантин відносяться до втручань, рекомендованих органами охорони здоров'я, щоб зменшити ймовірність розповсюдження інфекції. Разом 3 цим існує низка досліджень, що свідчить про високу поширеність симптомів психологічного дистресу та навіть психічних розладів унаслідок карантину, а також необхідності дотримуватися соціальної дистанції.

Сприйняття епідемій та пандемій базується на лінгвістичній складовій, а саме на мовленні (Strong, 1990; Esslinger, Mall \& de Oliveira-Susa, 2002). Це свідчить про потужний вплив соціальних мереж та засобів масової інформації у сучасному світі. Унаслідок цього майже миттево може поширюватися дезінформація та панічні настрої.
Іншим негативним чинником $€$ те, що згідно з нейропсихологічними дослідженнями, вважається, що людям, аби по-справжньому співчувати іншим, потрібно бачити й чути один одного, що не може бути повністю компенсоване комунікацією онлайн. Тож, особисте спілкування й робоча взаємодія через інтернет може позбавляти людей базових умов для виникнення емпатії.

В умовах соціальної ізоляції стають ще важливішими дані досліджень, згідно з якими у соціальних мережах 3 переважанням текстового контенту (наприклад, Twitter) користувачі відчуватимуть себе більш відсторонено та самотньо, аніж користувачі соціальних мереж з великою кількістю зображень (наприклад, Instagram) (Pittman \& Reich, 2016). Це підкріплюється тенденцією переважання фотографрій та відео у соціальних мережах.

Методологія дослідження. Зважаючи на вищезазначені дані, було висунуто припущення, що життя в умовах пандемії негативно пов'язане з суб'єктивним благополуччям, причому соціальні мережі грають у цьому негативну роль.

Припущення включає наступні аспекти:

1. Показники складових суб'єктивного благополуччя $€$ нижчими у досліджуваних, які оцінюють ситуацію та наслідки пандемії фраталістично.

2. Середні показники складових психологічного благополуччя $є$ вищими у досліджуваних, які не працюють у медичній галузі. Негативний афект у медиків буде вищим.

3. Використання соціальних мереж зростає під час карантину, унаслідок чого позитивний афект знижуватиметься, а негативний, зі свого боку, зростатиме.

4. Чим більша кількість інформаційного простору людини заповнена темою коронавірусу, тим вищою буде ії̈ тривога та негативний афект загалом.

5. Тривалий карантин та пандемія у світі збільшуватимуть негативний афект та зменшуватимуть позитивний афект.

6. Досліджувані називатимуть важливими наслідками пандемії коронавірусу економічні та соціальні проблеми у найближчому майбутньому.

7. Досліджувані з вищою загальною самоефективністю матимуть також вищі позитивний афект та задоволеність життям, а також будуть оцінювати наслідки пандемії менш трагічно.

Оскільки дослідження мало за завдання дослідити тенденції зміни психологічного благополуччя під час пандемії у динаміці, було прийнято рішення зробити три хвилі опитування, запропонувавши респондентам лишити адресу електронної пошти для подальшого тестування. Це супроводжувалося максимально можливим збереженням анонімності.

Перша хвиля опитування - це збір даних на початку введення карантину (18-23.03.2020). Друга хвиля - через тиждень після першої. Третя хвиля - збір даних через місяць від першої.

Було виокремлено об'єктивні та суб'єктивні кореляти суб'єктивного благополуччя. Наше дослідження присвячене виявленню зв'язку саме суб'єктивних параметрів із суб'єктивним благополуччям в умовах пандемії. Однак ми також здійснюватимемо контроль таких об'єктивних чинників, як:

- стать;

- вік;

- наявність дітей;

- рід професійних занять.

Було виокремлено низку корелятів суб'єктивного благополуччя:

1. Релігійність. Для загальних показників психологічного благополуччя у ряді робіт відзначається важливим 
фактором релігійність людини. Дослідження свідчать, що релігійні люди, загалом, повідомляють про вищі показники щастя і благополуччя, їхня соціальна самооцінка і психологічна адаптація $€$ оптимальнішою. Потенційними механізмами впливу релігійності на благополуччя називають соціальну підтримку та відчуття спільності з іншими, позитивний ефект від відчуття контакту з вищою силою, сенс та мету життя а також здоровіший спосіб життя, зумовлений слідуванню релігійним доктринам, відповідно до яких тіло сприймається як храм (Abdel-Khalek, 2019).

2. Час на персональні інтереси. Оскільки під час карантину, час перебування вдома збільшується, існує можливість, що час, який людина витрачатиме на на хобі також зросте, що зі свого боку вплине на психологічне благополуччя.

3. Час на фрізичну активність. Низка досліджень пов'язує фізичну активність та психологічне благополуччя, і це $\epsilon$ ефективною стратегією для підвищення благополуччя у дорослих (Kim et al., 2017). Проте, фрізична активність на свіжому повітрі призводять до нижчої тривожності, тоді як фрізичні навантаження в приміщенні мають наслідком дещо вищу тривожність (Lawton et al., 2017).

4. Соціальні мережі. 3 одного боку, соціальні мережі виконують важливу функцію у творенні власної ідентичності та самоактуалізації, що зі свого боку $є$ необхідним компонентом благополуччя особи. Однак з іншого боку, зловживання соціальними мережами може мати руйнівний ефект на благополуччя особистості. Це включає надмірне використання, залежність та прокрастинацію в мережах.

В умовах самоізоляції соціальні мережі набувають ще одного важливого значення. Емоційна підтримка позитивно впливає на почуття благополуччя, приналежності, людина почувається менш самотньо. Неодноразово користувачами соціальних мереж зазначається, що вони використовують соціальні мережі задля емоційної підтримки, коли в реальному світі нікого немає поряд (Lloyd, 2014; Valkenburg, 2006).

Блок з питаннями на кшталт "Скільки часу на день ви проводите в соціальних мережах у середньому?" націлений на те, аби виявити ступінь користувацької активності у різних соціальних мережах та мету. Також було включено низку питань на тему кількості інформації про коронавірус та епідемію, яку людина бачить у стрічці соціальних мереж.

5. Оцінка загрози для здоров'я. Негативна емоційність, також відома як нейротизм - це загальна тенденція легко зазнавати негативних наслідків від неприємних подразників. Люди, які високо оцінюють цю ознаку, як правило, відчувають неприємні емоції, такі як тривожність, дратівливість та депресія у відповідь на стресори. Негативна емоційність також пов'язана з тривогою з приводу загального здоров'я (Fergus, Bardeen \& Orcutt, 2015). Тривога може стосуватися як власного здоров'я, так і здоров'я близьких. Страх за себе та родину $є$ одним з ключових предикторів негативного афекту та низького суб'єктивного благополуччя взагалі.

6. Оцінка економічних наслідків. Економічна ситуація $€$ одним $з$ важливих стресорів під час пандемії та карантину. Економічні проблеми на рівні окремої особи, країни та світу загалом можуть підвищувати тривогу стосовно теперішнього та майбутнього. Люди з більшими економічними ресурсами мають більші можливості для отримання належної медичної допомоги та для уникнення зараження, натомість нестача коштів може унеможливите належне лікування.

7. Міри профрілактики, карантин. Вони мають дві сторони, адже з одного боку, застосовуючи якомога більшу кількість мір профрілактики, людина може відчувати себе спокійно, однак це може працювати і навпаки - чим тривожніше, тим більше людина вдається до мір профрілактики. Люди з високим рівнем непереносимості невизначеності намагаються зменшити невизначеність за допомогою поведінки, як-то перевірка та заспокоєння (Shihata et al., 2016). У випадку невизначеності, пов'язаної зі здоров'ям, це може включати неодноразові пошуки в інтернеті медичної інформації, наполегливий пошук заспокоєння у лікарів та слідування усім можливим захисним заходам (Bottesi, Ghisi, Sica \& Freeston, 2017; Fergus, 2015; Lauriola et al., 2018).

8. Оцінка впливу епідемії на повсякденне життя. Оцінка наслідків може залежати як від особливостей людини, так і від сукупності інших виокремлених нами конструктів. Загалом під час пандемії майже усі зіштовхуються з невизначеністю у сферах здоров'я, економіки тощо. Високий ступінь непереносимості невизначеності пов'язаний з цілою низкою неприємних симптомів, включаючи симптоми афективних розладів, об сесії та компульсії тощо (Shihata, McEvoy, Mullan, \& Carleton, 2016).

9. Оцінка довіри джерелам масової інформації. Переконання та побоювання щодо захворювань, подібно до самих хвороб, поширюються через спілкування у соціальних мережах або через медіа. Медіа можуть перебільшувати чи применшувати гостроту повідомлень, які хочуть передати експерти чи органи охорони здоров'я. Довіра до різних джерел є важливою, оскільки переконання людей позначаються на їхній поведінці, яка, зі свого боку, прямо впливає на швидкість поширення інфекції.

10. Конспірологічне мислення. Спалахи хвороб зазвичай $є$ популярним предметом теорій змов, особливо коли природа захворювання недостатньо вивчена (або особи, які вірять у теорії змови, не бажають знайомитися з результатами наукових досліджень та приймати їх серйозно. Зокрема, стосовно пандемії СНІДу існує чимало необґрунтованих теорій змови, які стверджують, що ВІЛ/СНІД - це біологічна зброя, призначена для знищення гомосексуалів або вчинення расового геноциду афроомериканців (Helier, 2015). Конспірологічні теорії виникають здебільшого у різкому протистоянні офріційній точці зору чи домінуючому дискурсу. Такі теорії можуть дати просту, зрозумілу картину актуальної загрози, невизначеної ситуації: чому щось трапилося, хто отримує з цього зиск і кого слід звинувачувати (Weigmann, 2018).

Дуже часто конспірологічні ідеї просуваються саме в соціальних мережах (наприклад, Facebook, YouTube), де їхні прихильники використовують критичні питання, "просто запитуючи", щоби посіяти сумніви в доречності офріційної або домінуючої перспективи.

11. Тривалість пандемії та оцінка можливості створення вакцини. Тривожність пов'язана з різними явищами, включаючи перебільшення загрози. Люди, які перебільшують негативність загрози, як правило, вважають себе особливо вразливими до загроз (Frost \& Steketee, 2002; Moritz \& Pohl, 2009). Люди, які визначають високу оцінку потенційної загрози, швидше за все, схвалюють твердження на кшталт "Я вважаю, що світ небезпечне місце" та будуть прогнозувати розвиток пандемії за гіршими сценаріями.

Для лонгітюдного дослідження було вирішено додати показник тривоги для ії̈ оцінки та порівняння відповідей в усіх хвилях. Рівень тривоги протягом тривалої пандемії може знижуватися. Проте, попри адаптацію до стресу, загальні показники суб'єктивного благополуччя усе одно мають бути нижчими. 
Першою методикою для виміру суб'єктивного благополуччя є Шкала задоволеності життям (Е. Дінер) короткий 5-елементний інструмент, призначений для загальної оцінки задоволеності життям.

Другою методикою стала шкала позитивного афекту та негативного афекту (PANAS). Досліджуваним необхідно оцінювати, якою мірою вони відчували себе в певному стані саме протягом останніх кількох тижнів у першій хвилі опитування. У другій хвилі, яка концентрувалась на одному тижні, відповідно була варіація інструкції до методики. У третій хвилі опитування, яке відбувалося через місяць від першої, досліджуваним пропонувалося оцінювати своє самопочуття протягом останніх двох тижнів.

Третьою методикою є "Шкала загальної самоефективності" Р. Шварцера та М. Єрусалема. Самоефективність - це впевненість (переконання) людини щодо наявності у неї потенційних здібностей організувати i здійснити власну діяльність, необхідну для досягнення певної мети. Самоефективність також розуміється і як продуктивний процес інтеграції когнітивних, соціальних і поведінкових компонентів з метою здійснення оптимальної стратегії в різноманітних ситуаціях. Відчуття людиною власної самоефективності певного рівня може бути ключовим предиктором для сприйняття подій та впливу на психологічне благополуччя в умовах пандемії.

Також у зв'язку з відсутністю україномовної адаптації низки використовуваних методик було проведено статистичний аналіз внутрішньої узгодженості використовуваних шкал на українській вибірці. а Кронбаха (0.85-0.87) і $\lambda 6$ Гутмана (0.83-0.89) мають високі значення для кожної досліджуваної змінної, що свідчить про достатню узгодженість усіх шкал.
Вибірка фрормувалася весною 2020 року. Рекрутинг відбувався у соціальних мережах facebook та Instagram. Для збору даних застосовувалася платформа $1 \mathrm{ka} . \mathrm{si}$. Всі досліджувані заповнювали методики анонімно і добровільно. Загальна кількість досліджуваних, які відповіли на всі питання батареї методик, склала 1339 осіб, з них було видалено відповіді тих, хто вказав свій вік як 9, 14, 16 та 212. Кінцева кількість досліджуваних склала 1332 особи, з них 218 чоловіків, 1109 жінок, а також 5 осіб визначили свою гендерну належність як "іншу". Вік - від 17 до 72. Середній вік: 34.46, стандартне відхилення: 11.63 , медіана: $35.48 \%$ досліджуваних першої хвилі мають дітей, i, відповідно, 52\% не мають дітей.

Дані про зв'язок типу професійних занять із психологічним благополуччям особистості $є$ вельми суперечливими, однак зазвичай безробіття здійснює стабільний та негативний вплив на психологічне самопочуття людей. Складовою дослідницького припущення $є$ і те, що середні показники складових психологічного благополуччя $€$ вищими у досліджуваних, які не працюють у медичній галузі. Негативний афект у медиків, відповідно до очікувань, має бути вищим. Вибірка складалась 3 $22 \%$ студентів, 5\% досліджуваних, які працюють у медичній сфрері та $11 \%$ осіб, які безробітні.

Результати кореляційного та порівняльного дослідження. Загалом в Україні на час початку пандемії позитивний афект (28.4) превалює над негативним (23.47) (табл. 1). За шкалою задоволеності життям показник (22.45) досліджуваних $€$ середнім, що свідчить про середній рівень задоволеністю життям. Тож, респонденти в основному задоволені своїм життям, але виділяють 1-2 значущих для них сфрер, які потребують досить серйозного поліпшення. Самоефективність досліджувані також оцінили у середньому у середній рівень.

Описові (дескриптивні) статистики за вибіркою

Таблиця 1

\begin{tabular}{|c|c|c|c|c|c|}
\hline Змінна & Середнє & Стандартне відхилення & Медіана & Асиметрія & Ексцес \\
\hline Задоволеність життям & 22.45 & 5.54 & 23 & -0.38 & -0.27 \\
\hline Позитивний афект & 28.4 & 7.06 & 29 & -0.06 & -0.23 \\
\hline Негативний афект & 23.47 & 7.65 & 23 & 0.41 & -0.43 \\
\hline Самоефрективність & 29.66 & 4.18 & 30 & -0.09 & 0.81 \\
\hline
\end{tabular}

Однією зі змінних, пов'язаних з психологічним благополуччям в умовах пандемії $€$ вік. Було виявлено достатньо сильний зв'язок між віком та використанням соціальних мереж: Facebook ( $\left.r=0,5, p=0.0000^{\star * \star}\right)$, Instagram $\left(r=-0,53, p=0.0000^{\star * *}\right)$, Telegram $(r=-0,56, p=$ $\left.0.0000^{* \star *}\right)$ та меншою мірою YouTube $(r=0,31, p=$ $\left.0.0000^{* * *}\right)$. Оцінка економічних наслідків у світі також має невеликий зв'язок з віком $\left(r=-0,23, p=0.0000^{\star \star \star}\right)$, тобто чим старші люди, тим частіше вони використовують соціальні мережі та мають песимістичніші очікування щодо економіки. Вік також було пов'язано і з кількома конспірологічними ідеями, а особливо помірний зв'язок $є$ з думкою, що під приводом коронавірусу влада бажає зменшити свободу людей $\left(r=0,31, p=0.0000^{\star * *}\right)$.

Важливою $€$ наявність дітей, яка може бути чинником, який посилює тривогу, попри той фракт, що дітям нова інфекція, судячи з актуальних даних, загрожує мало. Тим не менше, діти, особливо маленькі, можуть робити людину менш мобільною - той фракт, що людина відповідальна не лише за себе, $є$ важливим чинником психічного життя.

Оскільки в досліджуваній вибірці чоловіків з дітьми (72) значно менше, ніж чоловіків без дітей (146), доцільним $€$ порівняння чотирьох груп за критеріями гендерної належності та наявності дітей.

Таблиця 2

Аналіз досліджуваних за наявністю дітей та час на персональні інтереси

\begin{tabular}{|l|l|l|}
\hline \multicolumn{1}{|c|}{ Середнє } & \multicolumn{1}{|c|}{ Стандартне відхилення } \\
\hline Чоловіки з дітьми $(\mathrm{n}=72)$ & 3.43 & 1.21 \\
\hline Чоловіки без дітей $(\mathrm{n}=146)$ & 4.16 & 1.15 \\
\hline Жінки з дітьми $(\mathrm{n}=564)$ & 3.37 & 1.15 \\
\hline Жінки без дітей $(\mathrm{n}=545)$ & 3.9 & 1.22 \\
\hline
\end{tabular}

Існують значущі відмінності ( $\left.p=2.2 \mathrm{e}-16^{* \star *}, \eta 2=0.06\right)$ у тому, скільки часу респонденти витрачають на персональні інтереси. Аналіз post hoc, критерій Тьюкі для множинних попарних порівнянь показав, що значущими $\epsilon$ відмінності між групами чоловіків з дітьми та чоловіків без дітей $\left(p=0.0001^{* * *}\right)$, жінок без дітей та чоловіків з дітьми ( $\left.p=0.009^{* *}\right)$, жінок з дітьми та чоловіків без дітей $\left(p=0.0000^{* * *}\right)$ та жінок без дітей і жінок з дітьми 
$\left(p=0.0000^{* * *}\right)$. Так, ми бачимо, що найбільше приділяють часу персональним інтересам чоловіки без дітей, чоловіки з дітьми і жінки з дітьми приділяють приблизно однакову кількість часу, і найменше часу на хобі мають жінки з дітьми.

Релігійність виявилася не пов'язаною з особливостями переживання позитивних та негативних емоцій, суб'єктивним благополуччям особистості та її самоефективністю в умовах пандемії, що суперечить деяким даним, отриманим на вибірках західних країн та України. Жоден зв'язок з цими змінними не виявився статистично значущим ( $p>0.05)$.

Іншою змінною, пов'язаною з суб'єктивним благополуччям в умовах пандемії $є$ віра у теорії змови. Виявилося, що в теорії змови жінки вірять більше за чоловіків (mean = 17.68 проти 14.56 відповідно), статистична значущість порівняння за t-критерієм Ст'юдента складає 6.896e-13. d Коена складає 0.5, себто половину стандартного відхилення. Віра в теорії змови щодо коронавірусу корелює 3 релігійністю (коефріцієнт кореляції Спірмена) на рівні $r=0.27, p=2.2 \mathrm{e}-16$. Зі свого боку, зв'язок віри в теорії змови щодо коронавірусу та задоволеності життям, позитивним та негативним афектом, $€$ незначущим. Кореляція з загальною самоефективністю значуща ( $\mathrm{p}=$ $0.008)$, проте є надзвичайно слабкою $(r=0.07)$.

Відповідно до висунутого припущення ми очікували отримати відмінності в психологічному стані та сприйнятті хвороби у працівників медичних установ та i ншими досліджуваними. Медичних працівників (лікарів та медсестер) у вибірці було 71, не медиків - 1262.

Задоволеність життям у медичних працівників

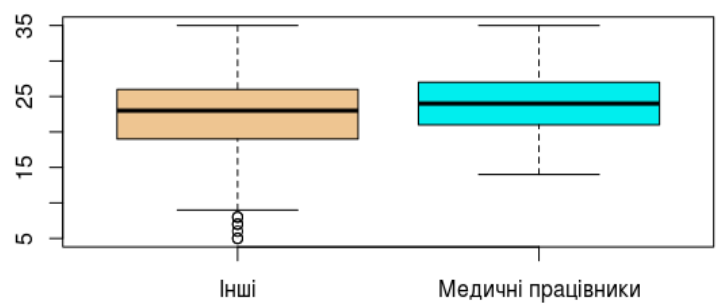

Рис. 1. Задоволеність життям у медичних працівників

У низці показників (використання соціальних мереж, оцінка загрози здоров'ю спалаху коронавірусу, оцінка економічних наслідків, міри профілактики коронавірусної інфрекції) на початок епідемії (18-23 березня) відмінностей між працівниками медичних установ та іншими досліджуваними виявлено не було. Однак у показниках суб'єктивного благополуччя було вивлено невеликі відмінності. Задоволеність життям за шкалою суб'єктивного благополуччя Е. Дінера у медичних працівників вища на чверть стандартного відхилення (d Коена: 0.25). За шкалою позитивного та негативного афекту медики мають вищий позитивний афект (d Коена: 0.32), а негативний - нижчий (d Коена: -0.27).

Під час нашого дослідження медичні працівники були на етапі підготовки, а кількість хворих не була велика, тоді їхні вельми високі показники індексів суб'єктивного благополуччя можна тлумачити як результат мобілізації, психологічної підготовки до роботи у складних умовах. Варто наголосити також на тому фракті, що через рекрутинг досліджуваних у соціальних мережах репрезентативність даних не було забезпечено, а медичні працівники у соціальних мережах можуть відрізнятися за віком та соціальним статусом від тих, хто в них не активний або відсутній.

Весь блок оцінки наслідків для здоров'я було пов'язано з оцінкою наслідків пандемії достатньо сильним кореляційним зв'язком ( $\left.r=0,44, p=0.0000^{* * *}\right)$. Відповідно до очікувань, оцінка наслідків для здоров'я має помірний зв'язок з конспірологічними теоріями, як, наприклад, те, що коронавірус небезпечніший, ніж про нього кажуть, а від людей приховують правду про великі масштаби епідемії $\left(r=0,31, p=0.0000^{* * *}\right)$. Також чим більшим $€$ рівень тривоги стосовно наслідків для власного здоров'я, тим вищим $€$ негативний афект $(r=0,21$, $\left.\mathrm{p}=0.0000^{\star * \star}\right)$, однак оцінка наслідків для здоров'я близьких ще сильніше кореляцію з негативним афектом $\left(r=0,26, p=0.0000^{* * *}\right)$.

Оцінка економічних наслідків епідемії сильно корелює з оцінкою впливу пандемії на буденне життя після її завершення $\left(r=0,47-0,51, p=0.0000^{\star * *}\right), 3$ оцінкою впливу пандемії на здоров'я $(r=0,25-0.35, p=$ $\left.0.0000^{* * *}\right)$, а також помірний зв'язок з деякими конспірологічними твердженнями, особливо з тим, що коронавірус небезпечніший, ніж про нього кажуть, а від людей приховують правду про великі масштаби епідемії $\left(r=0,21, p=0.0000^{* * *}\right)$. Невеликий зв'язок $€$ між прогнозуванням економічних наслідків та задоволеністю життям $\left(r=0,13, p=0.0000^{* * *}\right)$, що свідчить про негативні настрої у цій сфрері. Удвічі більший зв'язок між оцінкою економічних наслідків та негативного афекту $\left(r=0,20-0.25, p=0.0000^{\star * *}\right)$.

Зв'язок за способом проведення часу на карантині також має різницю у залежності від того, чим переважно займаються досліджувані. Так, перегляд онлайн курсів та читання книг має помірний зв'язок із позитивним афектом респондентів $\left(r=0,21-0.23, p=0.0000^{\star \star \star}\right)$, у той час коли гортання стрічки в соціальних мережах - із негативним $\left(r=0,25, p=0.0000^{\star * *}\right)$, а особливо з такими почуттями, як пригнічення, зляканість, невпевненість, занепокоєння та тривога. Також перегляд курсів, фрільмів та читання книг позитивно меншою мірою, але має зв'язок з почуттям самоефективності $\left(r=0,16, p=0.0000^{* \star *}\right)$, а гортання стрічки - негативно $\left(r=-0,12, p=0.0000^{\star \star *}\right)$.

Оцінка впливу пандемії після ії̈ завершення на буденне життя була пов'язана з усіма конспірологічними твердженнями, а в особливості з тим, що рівень небезпеки вірусу свідомо приховується $\left(r=0,25, p=0.0000^{\star * *}\right)$. Було встановлено помірний зв'язок оцінки впливу пандемії 3 негативним афектом $\left(r=0,33, p=0.0000^{\star \star \star}\right)$.

Із саморозвитком респонденти пов'язали Instagram $\left(r=0,27, p=0.0000^{* * *}\right)$ та Telegram $(r=0,37, p=$ $\left.0.0000^{* * *}\right)$, а з прокрастинацією лише Telegram $(r=0,21$, $\left.p=0.0000^{* * *}\right)$. Використання Instagram пов'язане з оцінкою наслідків для здоров'я людей в усьому світі $\left(r=0,25, p=0.0000^{* * *}\right)$. Також було виявлено, що проведення часу на карантині пов'язують із спілкуванням 3 близькими активніші користувачі Instagram ( $r=0,29$, $\left.p=0.0000^{* * *}\right)$ та Telegram $\left(r=0,35, p=0.0000^{* * *}\right)$.

Були отримано дані про те, що чим більше досліджувані використовують соціальні мережі на пошук інформації про коронавірус, тим більше це пов'язано 3 оцінкою наслідків пандемії $\left(r=0,2, p=0.0000^{* * *}\right)$. Віра в конспірологічні теорії була пов'язана з використанням Facebook $\left(r=0,28, p=0.0000^{* * *}\right)$, а особливо $з$ думкою, що під приводом коронавірусу влада бажає обмежити свободу людей. Також чим більше досліджувані шукають інформацію про коронавірус, тим більше проявляється зворотній зв'язок з переконанням, що коронавірус становить не більшу загрозу, ніж звичайний сезонний грип $\left(r=-0,22, p=0.0000^{* * *}\right)$.

Стосовно задоволеності життям та соціальними мережами зв'язку встановлено не було, однак чим більше вони використовуються для саморозвитку, тим вищим $є$ позитивний афект $\left(r=0,25, p=0.0000^{* * *}\right)$, а чим більше для прокрастинації $\left(r=-0,24, p=0.0000^{\star * *}\right)$, тим мен- 
шим $є$ показник позитивного афректу і вищим показник негативного афекту $\left(r=0,22, p=0.0000^{\star * *}\right)$. Було встановлено помірний зв'язок між використанням соціальних мереж для отримання інфрормації про вірус та негативним афектом $\left(r=0,28, p=0.0000^{* * *}\right)$, а також наступними емоціями: зляканість, занепокоєність та тривожність.

Самоефективність має значущий зв'язок з позитивним афектом досліджуваних $\left(r=0,47, p=0.0000^{\star \star *}\right)$, помірний - із задоволеністю життям ( $r=0,34, p=$ $0.0000^{* * *}$ ) та помірну зворотню кореляцію з негативним афектом $\left(r=-0,31, p=0.0000^{* * *}\right)$. Таким чином, можна сказати, що віра в ефрективність власних дій значною мірою пов'язана не лише 3 поведінкою, а й з суб'єктивним благополуччям людини.

Результати лонгітюдного дослідження. Було виявлено зменшення рівня тривоги стосовно здоров'я, респонденти почали оцінювати загрозу своєму здоров'ю та близьким як меншу, ніж на початку (mean1 = 3,7; mean3 $=2,7)$. Те ж стосується і оцінки економічних наслідків $($ mean $1=4,4 ;$ mean3 $=3,1)$.

Таким чином, загалом негативний афект дещо зменшився, особливо зменшились рівні зляканості (mean1 $=2,1$; mean $3=3,1)$ та занепокоєння $($ mean $1=3$; mean3 $=2,4)$, проте позитивний афект не зріс.

За результатами проведення кореляційного аналізу, було виявлено невеликі зв'язки думки про потребу посилення карантинних заходів та активністю у таких соціальних мережах як Instagram $\left(r=0.2, p=0.0000^{\star * *}\right)$ i Telegram $\left(r=0,23, p=0.0000^{\star * \star}\right)$, та зворотню кореляцію і використанням Facebook $\left(r=-0.27, p=0.0000^{* * *}\right)$. Оцінка рівня карантинних заходів для приборкання епідемії та рівень тривоги,у порівнянні з попереднім опитуванням, $\epsilon$ помірно пов'язаною $з$ оцінкою наслідків епідемії для здоров'я $\left(r=0.3-0.46, p=0.0000^{* * *} ; r=\right.$ $\left.0.16-0.27, p=0.0000^{\star * *}\right)$.

Проведення карантину з переглядом онлайн курсів, фрільмів та читанням книг мало більш значний зв'язок 3 позитивним афектом, аніж на початку епідемії, а особливо з захопленістю $(r=0,34)$, зацікавленістю $(r=0,35$, $\left.p=0.0000^{\star * *}\right)$, впевненістю $\left(r=0,21, p=0.0000^{* * *}\right)$ та бадьорістю $\left(r=0,25, p=0.0000^{* * *}\right)$. Спілкування з друзями та близькими онлайн мало невеликий зв'язок із почуттям радості $\left(r=0,17, p=0.0000^{* * *}\right)$ протягом останніх двох тижнів дослідження.

\section{Розподіл прогнозування наслідків за сферами}

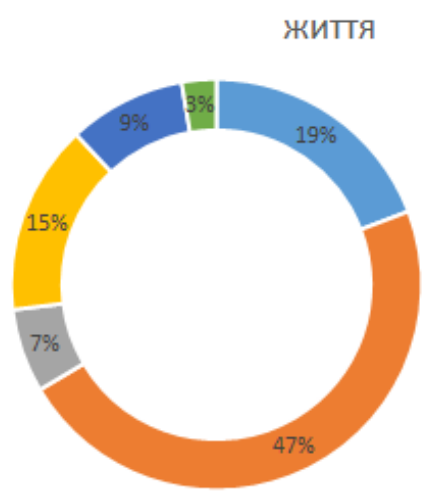

- Здоров'я

- Економіка

- Політика

= Соціум

- Психологія

- Екологія

Рис. 2. Розподіл прогнозування наслідків пандемії за сферами життя

Результати якісного дослідження оцінки наслідків пандемії. Було визначено, що станом на початок епідемії в Україні у досліджуваних превалюють негативні настрої у прогнозуванні наслідків. Стосовно розподілу прогнозування наслідків за сферами життя було встановлено, що майже половина усіх відповідей стосується економічної сфери, 19\% - теми здоров'я, 15\% соціальної сфрери, 9\% - психологічної сфрери, 7\% - політики та 3\% - екології.

Порівнюючи результати якісного аналізу прогнозування наслідків у першій хвилі та другій, можна стверджувати наявність невеликої динаміки. Так, кількість загальних нейтральних прогнозів у третій хвилі збільшилась, але кількість загальних позитивних зменшилась. У розподілі прогнозування наслідків за сферами життя у третій хвилі ми бачимо суттєве збільшення кількості прогнозів про суспільну сферу, а інші сфрери приблизно зберігають попередній відсотковий розподіл пропорційно.

Загальне обговорення результатів. 3 суб'єктивним благополуччям людей під час пандемії пов'язані наступні змінні: використання соціальних мереж, оцінка загрози для здоров'я та економічних наслідків, проведення вільного часу та самоефективність. Стосовно задоволеності життям та соціальними мережами загального зв'язку встановлено не було.

Відповідно до очікувань, оцінка наслідків епідемії коронавірусної інфекції для здоров'я має помірний зв'язок з вірою у конспірологічні твердження, відповідно до яких, зокрема, коронавірус небезпечніший, ніж про нього кажуть, а від людей свідомо приховують правду про жахливі масштаби епідемії. Також чим більшим $є$ рівень побоювань стосовно наслідків для власного здоров'я, тим вищим $€$ негативний афект, однак оцінка наслідків для здоров'я близьких мала ще сильнішу кореляцію 3 негативним афектом.

Невеликий зв'язок існує між прогнозуванням економічних наслідків задоволеністю життям та негативним афректом, що свідчить про негативні настрої досліджуваних у цій сфрері.

Зв'язок проведення часу на карантині також має відмінність у залежності від того, чим переважно займаються досліджувані. Так, перегляд онлайн-курсів та читання книг має помірний зв'язок із позитивним афектом респондентів, у той час як гортання стрічки у соціальних мережах - із негативним, а особливо з такими почуттями, як пригнічення, зляканість, невпевненість, занепокоєння та тривога.

Самоефективність має потужний зв'язок з позитивним афектом досліджуваних та із задоволеністю життям. Таким чином, можна сказати, що переконаність в ефективності власних дій значною мірою пов'язана не лише з поведінкою, а й психологічним благополуччям.

У лонгітюдному дослідженні було виявлено зменшення рівня тривоги стосовно здоров'я протягом місяця від початку карантину. Респонденти почали оцінювати загрозу своєму здоров'ю та близьким як меншу, ніж на початку. Те ж стосується й оцінки економічних наслідків. Таким чином, загалом негативний афект дещо зменшився, особливо зменшились рівні зляканості та занепокоєння, проте позитивний афект не зріс.

Деякі сучасні дослідники зауважують про можливість проблемного та надмірного використання соціальних мереж під час карантину та соціальної ізоляції (напр.. Király, 2020). Однак, згідно з нашими результатами, конструктивне проведення карантину 3 переглядом онлайн курсів, фрільмів та читанням книг мало потужніший зв'язок з позитивним афректом, аніж на початку епідемії, а особливо з захопленістю, зацікавленістю, впевненістю та бадьорістю. Спілкування з друзями та близькими онлайн не було сильно пов'язаним із почуттям радості протягом останніх двох тижнів дослідження.

Аналізуючи отримані результати в розрізі досліджень, які проводяться зараз, можна відмітити орієнтацію на вивчення соціальної взаємодії під час 
коронавірусної пандемії та ії̈ впливу на благополуччя. Ряд досліджень стверджує, що поліпшення регулювання емоцій та збільшення соціальної підтримки можуть бути оптимальними початковими цілями для зменшення впливу епідемії COVID-19 та карантинних обмежень на психічне здоров'я людини (Groarke, 2020; Yang, 2020). Саме такі демографічні показники як вік, сімейний статус, наявність дітей пов'язані з суб'єктивним благополуччям під час пандемії у Британії (Groarke, 2020), однак у нашому дослідженні не було виявлено прямого зв'язку.

Інші дослідження вивчали витоки обміну хибними повідомленнями та дезінформацією у соціальних мережах (Najmul, 2020), де деякі конструкти перегукувалися з конструктами в нашому дослідженні, наприклад, релігійності, пошуку розваг та інформації в інтернеті тощо. Таким чином було виявлено, що втома від соціальних мереж, пошук розваг, дефіцитна саморегуляція та релігійність передбачали неперевірений обмін інформацією про COVID-19 у соціальних мережах. Це дещо відрізняється від результатів, які були отримані нами.

Отже, суб'єктивне благополуччя під час пандемії пов'язане з використанням соціальних мереж, оцінкою загрози для здоров'я та економічних наслідків, зі способами проведення вільного часу та рівнем загальної самоефективності. Станом на початок епідемії в Україні у досліджуваних превалюють негативні прогнози наслідків епідемії та карантину. Протягом місяця у досліджуваних зменшився рівня тривоги стосовно здоров'я, оцінка загрози своєму здоров'ю та економічні наслідки сприймалися легше, ніж на початку. Загалом негативний афект у короткотривалій перспективі зменшився, особливо зменшились рівні страху та тривоги, проте рівень позитивного афректу не змінився. Протягом карантину на позитивний афект впливає якість проведення часу в соціальних мережах та інтернеті в цілому.

\section{Список використаних джерел}

1. Abdel-Khalek, A. M. (2019). Religiosity and well-being. Encyclopeadia of personality and individual differences. Switzerland: Springer Nature.10, 978-3.

2. Bottesi G., Ghisi M., Sica C., Freeston M. (2017). Intolerance of Uncertainty, Not Just Right Experiences, and Compulsive Checking: Test of a Moderated Mediation Model on a Non-Clinical Sample. Comprehensive Psychiatry 73:111-119.

3. Delle Fave A., Massimini A. F., Bassi M. (2011). Hedonism and eudaimonism in positive psychology. Psychological Selection and Optimal Experience Across Cultures. Netherlands, Dordrecht: Springer Netherlands. Vol. 2. P. 3-18

4. Diener, E. D., Emmons, R. A., Larsen, R. J., \& Griffin, S. (1985). The satisfaction with life scale. Journal of personality assessment, 49(1), 71-75.

5. Fergus, T. A., Bardeen, J. R., Orcutt, H. K. (2015). Examining the specific facets of distress tolerance that are relevant to health anxiety. Journal of Cognitive Psychotherapy, 29(1), 32-44.

6. Frost, R. O., Steketee, G. (2002). Cognitive approaches to obsessions and compulsions: Theory, assessment, and treatment. Pergamon/Elsevier Science Inc.

7. Groarke J., Berry E., Graham-Wisener L. (2020). Loneliness in the UK during the COVID-19 pandemic: Cross-sectional results from the COVID-19 Psychological Wellbeing Study

8. Király, Orsolya, Potenza. (2020). Preventing problematic internet use during the COVID-19 pandemic: Consensus guidance. Comprehensive Psychiatry.

9. Kim E. (2017). Maintaining Healthy Behavior: a Prospective Study of Psychological Well-Being and Physical Activity. Annals of Behavioral Medicine, Volume 51, Issue 3, Pages 337-347.

10. Lauriola, M., Mosca, O., Trentini, C., Foschi, R., Tambelli, R., \& Carleton, R. N. (2018). The intolerance of uncertainty inventory: validity and comparison of scoring methods to assess individuals screening positive for anxiety and depression. Frontiers in psychology, 9, 388.

11. Lawton E., Brymer E., Clough P., Denovan A. (2017) The Relationship between the Physical Activity Environment, Nature Relatedness, Anxiety, and the Psychological Well-being Benefits of Regular Exercisers. Front. Psychol. 8:1058.

12. Lloyd, A. (2014). Social media, help or hindrance: What role does social media play in young people's mental health? Psychiatria Danubina. № 26. p. 340-346.

13. Moritz S., Pohl R., (2009). Biased Processing of Threat-Related Information Rather Than Knowledge Deficits Contributes to Overestimation of Threat in Obsessive-Compulsive Disorder. Behavior modification 33(6):763-77

14. Najmul A. (2020). Misinformation sharing and social media fatigue during COVID-19: An affordance and cognitive load perspective. Technological Forecasting and Social Change.

15. Pittman M., Reich B. (2016). Social media and loneliness: Why an Instagram picture may be worth more than a thousand Twitter words. Computers in Human Behavior. Volume 62, Pages 155-167

16. Sampasa-Kanyinga, H., \& Lewis, R. F. (2015). Frequent use of social networking sites is associated with poor psychological functioning among children and adolescents. Cyberpsychology, Behavior, and Social Networking, 18(7), 380-385.

17. Shihata, S., McEvoy, P. M., Mullan, B. A., \& Carleton, R. N. (2016). Intolerance of uncertainty in emotional disorders: What uncertainties remain?. Journal of anxiety disorders, 41, 115-124.

18. Schwarzer, R., \& Jerusalem, M. (1995). Generalized self-efficacy scale. Measures in health psychology: A user's portfolio. Causal and control beliefs, 1(1), 35-37.

19. Strong, P. (1990). Epidemic psychology: a model. Sociology of Health \& Illness 12(3): 249-259.

20. Tang, L., Bie, B., Park, S. E., \& Zhi, D. (2018). Social media and outbreaks of emerging infectious diseases: A systematic review of literature. American journal of infection control, 46(9), 962-972.

21. Taylor, S. (2019). The psychology of pandemics: Preparing for the next global outbreak of infectious disease. Cambridge Scholars Publishing.

22. Utz, S., Breuer, J. (2017). The relationship between use of social network sites, online social support, and well-being: Results from a six-wave longitudinal study. Journal of Media Psychology: Theories, Methods, and Applications, 29(3), 115-125.

23. Valkenburg, P. M., Peter, J., \& Schouten, A. P. (2006). Friend networking sites and their relationship to adolescents' well-being and social self-esteem. CyberPsychology \& behavior, 9(5), 584-590.

24. Weigmann K. (2018). The genesis of a conspiracy. EMBO Rep 19:e45935

25. Watson, D., Clark, L. A., \& Tellegen, A. (1988). Development and validation of brief measures of positive and negative affect: the PANAS scales. Journal of personality and social psychology, 54(6), 1063-1070.

26. Yang C., Tsai J., Pan S. (2020). Discrimination and Well-Being Among Asians/Asian Americans During COVID-19: The Role of Social Media. Cyberpsychology, Behavior, and Social Networking.

\section{References}

1. Abdel-Khalek, A. M. (2019). Religiosity and well-being. Encyclopeadia of personality and individual differences. Switzerland: Springer Nature.10, 978-3.

2. Bottesi G., Ghisi M., Sica C., Freeston M. (2017). Intolerance of Uncertainty, Not Just Right Experiences, and Compulsive Checking: Test of a Moderated Mediation Model on a Non-Clinical Sample. Comprehensive Psychiatry 73:111-119.

3. Delle Fave A., Massimini A. F., Bassi M. (2011). Hedonism and eudaimonism in positive psychology. Psychological Selection and Optimal Experience Across Cultures. Netherlands, Dordrecht: Springer Netherlands. Vol. 2. P. 3-18

4. Diener, E. D., Emmons, R. A., Larsen, R. J., \& Griffin, S. (1985). The satisfaction with life scale. Journal of personality assessment, 49(1), 71-75.

5. Fergus, T. A., Bardeen, J. R., Orcutt, H. K. (2015). Examining the specific facets of distress tolerance that are relevant to health anxiety. Journal of Cognitive Psychotherapy, 29(1), 32-44.

6. Frost, R. O., Steketee, G. (2002). Cognitive approaches to obsessions and compulsions: Theory, assessment, and treatment. Pergamon/Elsevier Science Inc.

7. Groarke J., Berry E., Graham-Wisener L. (2020). Loneliness in the UK during the COVID-19 pandemic: Cross-sectional results from the COVID-19 Psychological Wellbeing Study

8. Király, Orsolya, Potenza. (2020). Preventing problematic internet use during the COVID-19 pandemic: Consensus guidance. Comprehensive Psychiatry.

9. Kim E. (2017). Maintaining Healthy Behavior: a Prospective Study of Psychological Well-Being and Physical Activity. Annals of Behavioral Medicine, Volume 51, Issue 3, Pages 337-347.

10. Lauriola, M., Mosca, O., Trentini, C., Foschi, R., Tambelli, R., \& Carleton, R. N. (2018). The intolerance of uncertainty inventory: validity and comparison of scoring methods to assess individuals screening positive for anxiety and depression. Frontiers in psychology, 9, 388

11. Lawton E., Brymer E., Clough P., Denovan A. (2017) The Relationship between the Physical Activity Environment, Nature Relatedness, Anxiety, and the Psychological Well-being Benefits of Regular Exercisers. Front. Psychol. 8:1058.

12. Lloyd, A. (2014). Social media, help or hindrance: What role does social media play in young people's mental health? Psychiatria Danubina. № 26. p. 340-346.

13. Moritz S., Pohl R., (2009). Biased Processing of Threat-Related Information Rather Than Knowledge Deficits Contributes to Overestimation of Threat in Obsessive-Compulsive Disorder. Behavior modification 33(6):763-77.

14. Najmul A. (2020). Misinformation sharing and social media fatigue during COVID-19: An affordance and cognitive load perspective. Technological Forecasting and Social Change.

15. Pittman M., Reich B. (2016). Social media and loneliness: Why an Instagram picture may be worth more than a thousand Twitter words. Computers in Human Behavior. Volume 62, Pages 155-167 
16. Sampasa-Kanyinga, H., \& Lewis, R. F. (2015). Frequent use of social networking sites is associated with poor psychological functioning among children and adolescents. Cyberpsychology, Behavior, and Social Networking, 18(7), 380-385.

17. Shihata, S., McEvoy, P. M., Mullan, B. A., \& Carleton, R. N. (2016). Intolerance of uncertainty in emotional disorders: What uncertainties remain?. Journal of anxiety disorders, 41, 115-124.

18. Schwarzer, R., \& Jerusalem, M. (1995). Generalized self-efficacy scale. Measures in health psychology: A user's portfolio. Causal and control beliefs, 1(1), 35-37.

19. Strong, P. (1990). Epidemic psychology: a model. Sociology of Health \& Illness 12(3): 249-259.

20. Tang, L., Bie, B., Park, S. E., \& Zhi, D. (2018). Social media and outbreaks of emerging infectious diseases: A systematic review of literature. American journal of infection control, 46(9), 962-972.

21. Taylor, S. (2019). The psychology of pandemics: Preparing for the next global outbreak of infectious disease. Cambridge Scholars Publishing.
22. Utz, S., Breuer, J. (2017). The relationship between use of social network sites, online social support, and well-being: Results from a six-wave longitudinal study. Journal of Media Psychology: Theories, Methods, and Applications, 29(3), 115-125.

23. Valkenburg, P. M., Peter, J., \& Schouten, A. P. (2006). Friend networking sites and their relationship to adolescents' well-being and social self-esteem. CyberPsychology \& behavior, 9(5), 584-590.

24. Weigmann K. (2018). The genesis of a conspiracy. EMBO Rep 19:e45935

25. Watson, D., Clark, L. A., \& Tellegen, A. (1988). Development and validation of brief measures of positive and negative affect: the PANAS scales. Journal of personality and social psychology, 54(6), 1063-1070.

26. Yang C., Tsai J., Pan S. (2020). Discrimination and Well-Being Among Asians/Asian Americans During COVID-19: The Role of Social Media. Cyberpsychology, Behavior, and Social Networking.

Надійшла до редколегії 20.07.20

Рекомендована до друку 15.10.20

Illia Yahiiaiev, PhD (Psychology), Associate Prof.,

Alina Novoselska, Student,

Vladyslava Keller, Student

Marta Savych, Student

Taras Shevchenko National University of Kyiv, Kyiv, Ukraine

\section{USING SOCIAL MEDIA AND SUBJECTIVE WELL-BEING DURING COVID-19 PANDEMIC}

The relevance of the topic is related to the psychosocial consequences of the COVID-19 pandemic. The aim is to study the subjective well-being during the beginning of the pandemic and introduction of the quarantine measures and their connection to social media activity. The methods employed in the present study include various types of questionnaires, namely the Positive and Negative Affect Schedule (PANAS) (Watson, Clark \& Tellegen, 1988), the Satisfaction With Life Scale (SWLS) (Diener, Emmnos, Larsen, \& Griffin, 1985), the General Self-Efficacy Scale (Schwarzer \& Jerusalem, 1995), and an original questionnaire developed to study the impact of the pandemic and the respondents' understanding and perceptions of it. The findings of the quantitative analysis show that the subjective well-being during the pandemic is connected to the use of social media, life satisfaction, health risks assessments and economic consequences, leisure time and the level of self-efficacy. A qualitative analysis indicates that at the beginning of the COVID-19 pandemic in Ukraine the negative predictions of the consequences of both the pandemic and the implemented quarantine measures prevail among the subjects. A longitudinal study during one month has found a reduction in health concerns, and respondents began to assess the threat to their health and economic consequences of the coronavirus pandemic as less serious than at the beginning. Thus, it can be concluded that from a short-term perspective the negative affect, especially the levels of fear and anxiety, decreased, whereas the level of the positive affect did not change.

Keywords: psychological well-being, subjective well-being, pandemic, life satisfaction, social media, conspiracy theories, COVID-19. 